Huldeblyk

\title{
Prof. dr. H.G. Stoker \\ (4 April 1899 - 16 Mei 1993)
}

\author{
N.T. van der Merwe \\ Emeritusprofessor \\ Dept. Filosofie \\ Potchefstroomse Universiteit vir CHO \\ POTCHEFSTROOM
}

Toe op 4 April 1899 te Johamnesburg vir Pieter Stoker en Leentje Nienhuis 'n seun gebore is, sou niemand van die familie kon vermoed dat een van die oorspronklikste wysgere van die twintigste eeu in die wieg lê nie. Tot standerd 8 was Hendrik Gerlardus 'n leerling aan die Duitse skool in Johannesburg en daarna aan die Potchefstroomse Gimnasium, waar hy in 1916 (eerste klas) matrikuleer. Begaafde onderwysers aan albei instellings het 'n onmiskenbare vormende invloed op sy persoonlikheid gehad, soos ook sy dosente aan die Literariese Departement van die Teologiese Skool op Potchefstroom, waar hy in 1917 die sogenaande 'Intermediate' en in 1919 die B.A. graad aan die PUK vir $\mathrm{CHO}$ met Sielkunde, Logika, Hollands, Engels, Latyn en Grieks as vakke in die finale eksamen verwerf. Twee jaar later word die M.A. graad in filosofie met onderskeiding deur UNISA aan hom toegeken. Die jong student was bevoorreg dat onder andere dr. J.D. du Toit (Totius) wat die wysgerige klimaat in Nederland uit eie ervaring geken het, oorreed kon word on 'n bepaalde aandeel aan sy vorming in die filosofie te neem. Op aandrang van sy vader verwerf hy ook die destydse $O .1$ onderwysdiploma sodat, al is daar nie 'n olywepers soos vir Thales in ou Griekeland in vooruitsig nie, daar darem vir 'n toekomstige filosoof ' $n$ venster op brood en botter geopen mag wees!

In 1922 kon Henk Stoker vir verdere studie na Nederland en Duitsland vertrek, waar hy kontakte van blywende waarde gemaak het. Aangesien leiding met die oog op 'n doktorsgraad in die filosofie aan die Vrije Universiteit te Amsterdam op dié stadium nie sinvol gereël kon word nie, is Stoker na Max Scheler in Keulen aanbeveel, waar hy na vier semesters Filosofie-, Opvoedkunde- en Sosiologiestudie in Keulen, en een in Berlyn, in Julie 1924 oor die filosofiese problematiek van die gewete met Arthur Sclmeider as koreferent gepromoveer het. Daama het hy nog een semester aan Filosofie, Sielkunde en Opvoedkunde te Keulen gewy 
voor hy na Suid-Afrika en na 'n benoeming aan sy Alma Mater teruggekeer het. Twee sake val in die besonder op: die jong akademikus het hom ook met eksperimentele Opvoedkunde en Sielkunde besig gehou en sy proefskrif was van só 'n kwaliteit dat dit nie alleen in Scheler se publikasiereeks "Schriften zur Philosophie und Soziologie" opgeneem is nie, maar vir dekades een van die weinige en beste studies oor die tema gebly het.

Vanaf 1925 was Stoker tot 1964 voltyds (eers as senior lektor en sedert 1930 as professor) en daana nog vyf jaar lank deeltyds as ere-professor aan die PUK en later PU vir $\mathrm{CHO}$ verbonde. Op 'n bepaalde stadium was hy tewens dekaan van die Fakulteit Lettere en Wysbegeerte. Saam met sy primêre taak as filosoof asook deskundige meewerking aan die Fakulteit Opvoedkunde, het hy die fondament vir 'n kragtige Departement Sielkunde gelê, totdat dié taak twaalf jaar later deur wyle prof. J.M. Hatting voortgesit is. Sy werkkrag en entoesiasme was onblusbaar. Met ywer en deursettingsvermoë stel hy krities-ondervragend en waarderend die Christelike filosofie van sy kollegas aan die Vrije Universiteit Vollenhoven en Dooyeweerd - in breë kring bekend. Self werk hy skerpsinnig en kreatief 'n eie nuanse uit, bekend as 'die Wysbegeerte van die Skeppingsidee'. Hiermee het hy dosyne studente - en ook belangstellende akademici versprei deur die land - geboei en begeester vir 'n "In U Lig"-perspektief. Op hul beurt het verskeie van sy oudstudente wat met die loop van tyd aan talle Suid-Afrikaanse universiteite en kolleges benoem is, met entoesiasme die grondprobleme van Christelike wetenskapsbeoefening verder ondersoek.

Verskeie geleerdes wat uit beginsel met hom van insig verskil het, het tog 'n groot respek vir sy intellektuele belesenheid, logies skerp insig, opsigtelike vakbekwaamheid en eerbied vir die feite gekoester. Hoewel dit ten diepste uit sy fassinering met die verskeidenheid van Gods skepping spruit, sou 'n mens dit ook só kon verduidelik: die fenomenologiese rigtingwyser van Husserl zum Sache selbst het by Stoker (hoewel hy self nader was aan die fenomenologie van Scheler en Buijtendijk as aan dié van Husserl) weerklank gevind in 'n passievolle toewyding om 'alle feite', die volle verskeidenheid, vas te stel voor tot 'n beoordeling gekom word. Die integriteit wat hieruit voortvloei, het menige teëstander tot versigtigheid en waardering gestem.

Stoker was bevoorreg met 'n buitengewoon sterk en taai gestel - eers in 1962 het hy 'n periode siekteverlof aangevra, na 37 jaar! Voeg hierby 'n sterk mentale dissipline, toewyding en detenninasie, en dit word begryplik hoe hy oor soveel dekades so 'n werksywer kon volhou. Op sy eie het hy dekades lank 'n wye verskeidenheid filosofiese deelwetenskappe vir voor- en nagraadse studente ontsluit. Sy veelsydigheid, breë vorming en wye belesenheid was veral vir die oopbreek van interdissiplinêre vraagstukke nuttig. Sy besondere gawe om die rol van filosofiese persoonlikhede te vertolk en 'n kritiese diskussie te ontlok, het sy 
klasse ' $n$ belewenis gemaak. As dosent het Stoker sy studente besiel omdat hy self ' $n$ rolmodel van toegewyde studie was en goed voorbereid sy klasse aangebied het. Vanuit sy roepingsbesef was dit vir hom vanselfsprekend. Vir die toeskouer bly dit ' $n$ raaisel hoe hy dit alles kon hanteer en dan nog daarby gereêlde toesprake en voordragte reg oor die land kon inpas om sy mense vanuit ' $n$ Calvinisties-Christelike wortel geestelik weerbaar te maak. Die merkwaardige is dat hierdie werklus tot op gevorderde leeftyd volgehou kon word. Só pak hy byvoorbeeld in sy menslik gesproke mees kosbare jare selfs nog die reuse taak aan om 'n Studium Universale-kursus vir die PU vir CHO in oorleg en samewerking met ' $n$ span kollegas uit diverse fakulteite te ontwerp, uit te werk, te toets en te verfyn totdat dit in die publikasie Beginsels en metodes in die wetenskap beslag gekry het en later die interfakultêre kursus Wetenskapsleer sou word.

Hoewel ek die geboorte-uur van hierdie projek met verwondering en verrassing gevolg het, het ek tog dikwels daaroor gewonder of dié energiebesteding, veral ook die eindelose ure nasienwerk, wel geregverdig was as ' $n$ mens daaraan dink dat briljante navorsingsresultate in omvangryke manuskripte, soos dié oor die tydsvorme, daardeur nie tot afronding kon kom nie. Maar dit staan vas dat die invloed wat van dié onderneming uitgegaan het, op sowel student en dosent, enorm was en baie daartoe meegewerk het om 'n belangrike wending te bring in die positivistiese botone wat vir dekades met die Christelike melodie aan die PUK bly meetril het. So het hy inderdaad verskeie akademici vir die eerste keer bewus gemaak dat ' $n$ wêreldwye revolusie in die wetenskapsteorie - en praktyk voltrek is. Menige knap vakgeleerde het hom beleef as hoog in die wolke en vér bo die kop van die gewone akademikus, sonder om te besef dat die angel in werklikheid sit in die agterstand wat die deursneewetenskaplike met wêreldtendense opgedoen het.

Die soort keuse hierbo genoem, wat ook in sy oprig en veeleisende instandhou van die Bulletin vir Christelike Wetenskap tot uitdrukking gekom het, het nie alleen saamgeliang met 'n diep roepingsbesef vir noodsaaklike arbeid in die koninkryk van God nie maar ook met 'n liefde om nuwe intellektuele weë te bewandel en die opgewondenheid en vreugde wat daaruit voortspruit - 'n werklik uitsonderlike gawe vir ontwikkelingsdinamika in die wetenskap. Die impak van sy voortbeurende ondersoekdrif sou veel kleiner gewees het as daarmee nie ook 'n voortreflike organisasietalent gepaard gegaan het nie - en die bereidheid om 'donkiewerk' sonder gemor uit te voer. Hierdie kombinasie is eintlik verbasend as ' $n$ mens ' $n$ derde faktor in oorweging neem, naamlik die sterk individualistiese 'eenmans'- werk- en skryfstyl van die Europees gevormde geslag van die twintigerjare, wat hy in baie opsigte met Dooyeweerd en Vollenhoven gedeel het.

'n Belangrike verklaring vir die verbasende uitset wat Stoker as akademikus kon volhou, is die steun wat sy eggenote Miriam du Plessis hom trou oor die dekades 
gebied het. Nagraadse studente sal die koppie tee en beskuitjie wat die diepgrypende voordragte van die leermeester op ' $n$ gepaste moment onderbreek het, altyd onthou. Maar sy was meer as tuisteskepper - het sy dan nie met haar koel praktiese kop die diepsinnige denker die sleutel tot die tydsproblematiek in hande gegee nie? Ook die kinders Pieter, Dawie en Erika het nie alleen intense gesinsvreugde besorg nie maar by geleentheid ook aanleiding tot filosofiese ontdekking en nadenke. Veral seun Pieter en kleinseun Henk het die filosofiese gawe geërf en op eie wyse gestalte gegee. Die mooie van sy verhouding tot sy studente was dat menigeen ' $n$ ware vriend en raadgewer in hom kon vind, ja eintlik in die koesterende strale van die huislike kring opgeneem is. En dan het nie ' $n$ ander mens na vore gekom nie, maar die ander fasette van ' $n$ veelsydige persoonlikheid: die mens wat na harde intellektuele arbeid behoefte aan 'n paar lekker geelbandontspanningsverhale het; die mens wat al wandelende met Miriam aan sy sy getrou mens en dier groet wanneer vroutjie die sein gee, terwyl die oë in die verte die kontoere van ' $n$ ingewikkelde teorie aftas; die mens wat byvoorbeeld tydens sy gaslesings aan die Vrije Universiteit met 'n ondeunde humorsin oneindige genot kon put om ongemerk lekkennye in die kombuis van ons Amstelveense verblyf te gaan wegsteek en dan fyntjies dop te hou of dit ontdek word! Die mens wat ' $n$ lekker maaltyd so intens kon geniet en waardeer; die mens wat ' $n$ hele preek in enkele begrippe op 'n sigaretdosie kon saamvat ... Ja, dit is die mens wat ons sal bly onthou: veelkantig soos die 'veelkleurige wysheid van God' wat 'n grondpyler van sy denke geword het in sy besondere toepassing van Efesiërs 3:10 op die onmeetlike verskeidenheid van die skepping.

Die filosofiese denke van Stoker was in hoë mate oorspronklik en dinamies: oor meer as vier dekades het dit ' $n$ gestadige voortgang en groei getoon, ook ' $n$ ontwikkelingsgang waarvan ons die kontoere moontlik nog nie finaal gepeil het nie. Die tyd is ryp om kleinseun Henk se onmisbare grondwerk aan die Stokerargief in geprogrammeerde navorsing te laat uitbot. Wat duidelik is, is dat die sentrale lewensbeskoulike betekenis van alle synde as 'n Skepping van God, Stoker met sy 'Skeppingsidee' telkens op verdere en verrassend nuwe intellektuele ontdekkingsweë binne die ryk verskeidenheid van die skepping gevoer het en tot merkwaardige verdieping van die vroeë oerintuïsie gevoer het. In sy filosofiese en intellektuele belangstelling was hy oop, in sy erkenning van ander bydraes ruim en erkentlik, in sy persoonlike selfevaluasie beskeie en bewus van eie beperkinge, in sy hantering van kritiek op sy sisteem miskien effens oorsensitief. Self het hy sy lewenswerk in 'n brief van 1 Mei 1981 insake sy benoeming as ereprofessor só verwoord: "Wat ek wel met 'n oop gewete kan sê,, is dat ek probeer het om my bes te doen. Ten slotte was dit alles genade."

Binne hierdie raamwerk pas ook die talle geleenthede en die erkenning wat hom by kongresse en vergaderings toebedeel is, asook eerbewyse wat hom te beurt geval het, soos onder andere ereprofessorate aan en eredoktorate van die PU vir 
CHO en die RAU; gaslesings aan die Vrije Universiteit (Amsterdam) en die Institute for Christian Studies (Toronto); erelidmaatskap van die Instituut vir Reformatoriese Studie; volle lid van die Suid-Afrikaanse Akademie vir Wetenskap en Kuns; 'n dekorasie vir voortreflike landsdiens; die Meestersprys van die Afrikaanse Literêre Vereniging; die Stalsprys vir filosofie van die Suid-Afrikaanse Akademie vir Wetenskap en Kuns en talle meer.

Stoker was in hart en niere 'n akademikus. Sy insette was egter nie net beperk tot sy universitêre taak nie. Oor sosiale, politieke, kerklike en ander aangeleenthede het hy ' $n$ eie siening gehad en dit prakties uitgeleef, soms meer eksplisiet, soms minder; en soms ook met meer en soms minder persoonlike selfverloëning en opofferinge. So het byvoorbeeld sy anti-imperialistiese, patriotiese en tot bepaalde hoogte nasionalistiese instelling daartoe aanleiding gegee dat sy Die stryd om die ordes die aanhaakpunt geword het vir sy internering gedurende die Tweede Wêreldoorlog. Self was Stoker oortuig dat hy in die toepassing van sy roeping in die openbare lewe nie die noodregulasies oortree het nie. Self het hy die bestierende hand van God ook in sy lewe daar as nommer K2231-42 beleef. Dit laat ' $n$ mens die diepgang van sy siening oor die naam van die mens aanvoel, die naam wat sy betekenis van die individuele draer ontvang. 'n Moeilike dilemma bly die samehang tussen kritiek, polemiek, apologetiek en verset, ook vir die jare daarna. Nietemin, die invloed wat van die Koffiefonteinse Akademie of sogenaamde Boere-universiteit op talle geinterneerdes uitgegaan het, was onvoorsiens belangrik ook vir latere jare. Die isolasie van die oorlogsjare asook die probleem om daarna persoonlike kontak op 'n gereelde basis met geesverwante en biblioteke oorsee te kan hê, maak die intensiteit en kwaliteit van sy navorsingswerk en filosofiese insigte des te meer merkwaardig.

'n Groot verskeidenheid belangrike onderwerpe het oor die jare sy belangstelling geprikkel en tot insiggewende publikasies ontluik: vryheid, reg, arbeid, opvoeding, geskiedenis, taal, mens, kennis en so meer. Sy publikasies sluit onder andere in monografieë, versamelwerke, tydskrifartikels, redaksionele riglyne, dagbladen radiobydraes. Vir my persoonlik is Praktiese Calvinisme ' $n$ juweeltjie: hierin sien ' $n$ mens 'n groot denker met diep menslike probleme worstel en antwoorde bied, antwoorde met ' $n$ besondere harnonie van teorie en praktyk. Oorsprong en rigting bly as versamelwerk 'n goudmyn om sy basiese filosofiese ideë te ontdek. Daaruit blyk hoe groot die invloed van die Calvinistiese wêreldbeskouing op hom was en hoe dit sy kostelike Skeppingsidee geïnspireer het.

Stoker was aktief betrokke by Die Wagtoring van sy ontstaan in 1921 en by die opvolger daarvan, naamlik Koers, waarvan hy vanaf deel V nr. 3 (1937) deel van die redaksie uitgemaak het. Merkwaardig genoeg was wêreldbeskouing juis die tema van sy eerste bydrae tot die eerste uitgawe van Die Wagtoring (p. 28-43):

Koers 58(3) 1993:267-272 
'Die opbou van 'n Kalvinistiese wêreldbeskouing'. Op bladsy 42 tref ' $n$ mens iets van die kenmerkende Stokerstyl aan:

\begin{abstract}
Alle waarhede, alle wette, alle prinsiepes wat elkeen van die oorspronklike sfere bied, moet as stof vir die opbouing van die wêreldbeskouing aanvaar word ... Die grondvraag egter vir 'n kalvinistiese, tenslotte vir elke filosofie, is die vraag van die verhouding van die universum in al sy sfere tot God ... Oor hierdie vrae kan geen eksperimentele, ook geen filosofiese wetenskap beslis. Hierdie vrae is uiteindelik geloofsvrae, waarmee elke mens begin, bewus of onbewus, in die opbouing van sy wêreldbeskouing, en die antwoord op die vrae, waarmee hy begin, karakteriseer sy hele wêreldbeskouing. Die Kalvinis sal hierdie vrae doelbewus beantwoord volgens die beantwoording, die waarheid, wat hy in die Heilige Skrif daarvan kry. 'n Kalvinistiese filosofie is deurgaans teosentries (God die middelpunt), erken die grense van die menslike rede, is dienaar van die waarhede, wat hom in elke sfeer objektief gegee is, en weet dat alle waarheid rus in die Skepper van die heelal, in God.
\end{abstract}

Dit is vanuit bogenoemde benadering wat Stoker later in ' $n$ brief gedateer 11 April 1982 sy noue verbondenheid met en lojale liefde vir die Potchefstroomse Universiteit kon verwoord:

$\mathrm{U}$ verwesenliking van $\mathrm{u}$ van God gegewe roeping sal ek met belangstelling bly volg! Vivat, crescat et floreat nostra universitas Christiana soli deo gloria!

Stoker se aardse roeping is beëindig. Ons eer sy nagedagtenis en mis sy warm menslike belangstelling, steun en aanmoediging. Ons bly die deurwerk van sy lewe en dade, veral sy verwoorde gedagtes, met belangstelling volg. Mag sy worstelinge met die groot vrae van $s y$ tyd ook vir menige leser van Koers koers vir die toekoms bied. 